\title{
PENGARUH ALOKASI ANGGARAN PENDAPATAN DAN BELANJA DAERAH (APBD) TERHADAP PENYERAPAN TENAGA KERJA DI KABUPATEN JEMBER
}

\author{
*(Laily Chodariyanti \\ Fakultas ekonomi \\ Universitas Islam Lamongan
}

\begin{abstract}
ABSTRAK
Makalah ini bertujuan untuk mengetahui pengaruh alokasi pendapatan Anggaran dan Kabupaten Belanja (APBD) terhadap penyerapan tenaga kerja di Kabupaten Jember. Metodologi yang digunakan adalah berdasarkan data sekunder dari berbagai sumber resmi sedangkan sampel yang digunakan adalah untuk periode 2004-2013. alat analisis data yang digunakan dalam penelitian ini adalah metode \analisis trend dan korelasi bivariat. Hasil analisis jawaban yang diperoleh bahwa penyerapan tenaga kerja di Kabupaten Jember akan meningkat sementara korelasi antara Pemerintah Kabupaten Jember menghabiskan dengan penyerapan tenaga kerja di Kabupaten Jember sangat kuat dan langsung.
\end{abstract}

Kata kunci: tenaga kerja, alokasi pendapatan Anggaran dan Belanja Kabupaten $(A P B D)$, jember

\section{PENDAHULUAN}

Kriteria utama keberhasilan pembangunan daerah adalah dalam bentuk Product Domestic Regional Bruto (PDRB) secara sektoral maupun perkapita (Iwan, 1994: 97). Oleh karena itu PDRB secara agregatif menunjukkan kemampuan suatu daerah dalam menghasilkan pandapatan atau balas jasa terhadap pemilik faktor-faktor produksi yang ikut berpartisipasi dalam pembangunan di daerah tersebut.

Salah satu kabupaten yang memiliki kemampuan dalam menghasilkan pendapatan dalaha kabupaten Jember. Pada tahun 2013, pendapatan kabupaten Jember mencapai 2.266.304.287.001,31 dan meningkat pada tahun 2014 menjadi Rp 2.667.046.916.473,00 (APBD kabupaten Jember,2014). Hal ini menyebabkan barang dan jasa yang diproduksi dalam perekonomian bertambah dan kemakmuran masyarakat meningkat sehingga tercipta kesempatan kerja yang tinggi.

Dalam mengejar keberhasilan pembangunan daerah, harus disertai dengan penciptaan lapangan kerja baru. Bukan sekedar pertumbuhan ekonomi tinggi, tetapi pertumbuhan kuantitas dan kulitas lapangan kerja melalui usaha ekonomi padat pekerja. Dalam hal ini Kabupaten Jember telah berusaha merealisasi penyerapan tenaga kerja dengan capaian 1.130 .595 orang pada 
tahun 2010 dan meningkat pada tahun 2011 sebesar 1.160.941 orang. Namun pada tahun 2013 menurun menjadi 1.104.777 orang (BPS Kabupaten Jember, 2013:154).

Investasi pemerintah melalui kebijakan fiskal dan moneter harus mempertimbangkan dan memberi prioritas pada sektor ekonomi (business) yang potensial seperti; sektor pertanian, manufaktur,makanan dan sektor jasa. Penyerahan kewenangan pemerintahan pusat kepada daerah disertai dengan kewenangan pengelolaan keuangan. Pemerintah daerah harus memiliki sumber-sumber penerimaan sendiri untuk membiayai pengeluaran (Simanjuntak, 1999: 20). Penerimaan daerah menurut Peraturan Menteri Dalam Negeri Nomor 13 Tahun 2006 tentang Pedoman Pengelolaan Keuangan Daerah adalah uang yang masuk ke kas daerah, sedangkan pendapatan daerah merupakan hak pemerintah daerah yang diakui sebagai penambah nilai kekayaan bersih. Penerimaan daerah ditunjukan dengan besaran Pendapatan Asli Daerah (PAD) yang dimiliki masing-masing daerah. Pendapatan asli daerah merupakan salah satu kriteria penting untuk mengetahui dan mengukur secara nyata kemampuan daerah dalam pelaksanaan otonomi daerah.

Analisis kinerja keuangan pada APBD dilakukan dengan membandingkan hasil yang dicapai dari satu periode dengan periode sebelumnya sehingga dapat diketahui bagaimana kecenderungan yang terjadi. Beberapa rasio yang dapat digunakan dalam menganalisis kinerja keuangan yang bersumber dari APBD antara lain: rasio kemandirian untuk menilai tingkat kemandirian keuangan daerah dalam membiayai penyelenggaraan otonomi daerah; rasio efektivitas menggambarkan kemampuan pemerintah daerah dalam mencapai target pendapatan asli daerah; rasio efisiensi untuk mengukur efesiensi dalam merealisasikan pendapatan daerah dan rasio keserasian.

Berdasarkan uraian latar belakang penelitian yang telah diuraikan, maka permasalahan yang ditemui adalah Seberapa besar pengaruh alokasi APBD pengeluaran pemerintah terhadap penyerapan tenaga kerja di Kabupaten Jember

Menurut teori Neo Klasik (SolowSwan) ini (dalam Arsyad, 1999: 61) pertumbuhan ekonomi tergantung kepada pertambahan penyediaan faktor-faktor produksi (penduduk, tenaga kerja dan akumulasi modal) dan tingkat kemajuan teknologi. Pandangan teori ini didasarkan kepada anggapan yang mendasari analisis Klasik, yaitu perekonomian akan tetap mengalami tingkat pengerjaan penuh (full employment) dan kapasitas peralatan modal akan tetap sepenuhnya digunakan sepanjang waktu. Dengan kata lain, sampai dimana perekonomian akan berkembang tergantung pada pertambahan penduduk, akumulasi kapital dan kemajuan teknologi.

Selanjutnya menurut teori ini, rasio modal-output (capital-output ratio) bisa berubah atau bersifat dinamis. Artinya untuk menciptakan sejumlah output tertentu, bisa digunakan besarnya modal yang berbeda-beda dengan bantuan tenaga kerja yang jumlahnya berbedabeda pula, sesuai dengan yang dibutuhkan. Jika lebih banyak modal yang digunakan, maka tenaga kerja yang dibutuhkan lebih sedikit. Sebaliknya jika modal yang digunakan lebih sedikit, maka lebih banyak tenaga kerja yang digunakan. Dengan adanya fleksibilitas ini, suatu perekonomian mempunyai kebebasan yang tak terbatas dalam menentukan kombinasi modal dan 
tenaga kerja yang akan digunakan untuk menghasilkan tingkat output tertentu.

Todaro

(2003:

92)

menyampaikan ada tiga faktor atau komponen utama dalam pertumbuhan ekonomi dari setiap negara. Ketiga faktor tersebut adalah:

1. Akumulasi modal, yang meliputi semua bentuk atau jenis investasi baru yang ditanamkan pada tanah, peralatan fisik, dan modal atau sumber daya manusia.

2. Pertumbuhan penduduk, yang pada akhirnya akan memperbanyak jumlah angkatan kerja.

3. Kemajuan teknologi, berupa cara baru atau perbaikan cara-cara lama dalam menangani pekerjaan-pekerjaan.

Menurut teori Klasik, akumulasi modal serta jumlah tenaga kerja memiliki peran yang sangat penting dalam pertumbuhan ekonomi. Smith menyebut ada tiga unsur pokok dalam produksi suatu negara, yaitu:

a. Sumber daya yang tersedia, yaitu tanah.

b. Sumber daya insani, yaitu jumlah penduduk.

c. Stok barang modal yang ada.

Konsep otonomi daerah sebagaimana diatur dalam Undangundang dirumuskan sebagai berikut "Otonomi daerah adalah hak, wewenang dan kewajiban daerah otonom untuk mengatur dan mengurus sendiri urusan pemerintahan dan kepentingan masyarakat setempat sesuai dengan peraturan perudangundangan".Sedangkan konsep daerah otonom dalam Undang-undang dirumuskan sebagai berikut "Daerah otonom yang selanjutnya disebut sebagai daerah, adalah kesatuan masyarakat hukum yang mempunyai batas-batas wilayah yang berwenang mengatur dan mengurus urusan pemerintah dan kepentingan masyarakat setempat menurut prakarsa sendiri berdasarkan aspirasi masyarakat dalam sistem Negara Kesatuan Republik Indonesia" (UU No. 32 Tahun 2004: 4).

Prasarana wilayah merupakan bagian yang tidak terpisahkan dari sistem perwilayahan dan tata ruang, maupun struktur pelayanan dan kegiatan (baik itu internal wilayah maupun keterkaitannya dengan eksternal wilayah). Tingkat urgensi ini dicerminkan dengan saling mempengaruhi antara perwilayahan dan keberadaan infrasruktur. Prasarana Wilayah terdiri atas: transportasi (darat, laut dan udara), irigasi (terkait dengan persediaan air dan sistem pengaliran irigasi), energi (listrik, gas), komunikasi (telepon, berkait dengan pengembangan dan sistem jaringan), tata air (drainase, dan air baku).

Untuk menunjang pemerataan pembangunan, peranan transportasi sangat dominan sebagai akses penghubung antar wilayah dan mendukung kegiatan koleksi dan distribusi barang dan jasa. Adapun kajian transportasi ini terdiri atas trnsportasi darat, laut dan udara.

Transportasi darat dapat dibagi menjadi 3 (tiga) kelompok yakni jalan raya, kereta api dan penyeberangan. Jalan raya dalam hal ini akan terkait dengan: jaringan jalan, terminal penumpang, terminal kargo dan peti kemas; sedangkan kereta api mengkaji tentang jaringan dan tipe pelayanan.

Jaringan jalan memegang peran utama dalam mendorong pertumbuhan wilayah maupun pelayanan pergerakan barang dan manusia. Arahan pengembangannya didasarkan atas orde kota, tingkat perkembangan kota, hubungan antar wilayah yang lebih luas. Sistem jaringan jalan terdiri atas sistem 
jaringan jalan primer dan sistem jaringan jalan sekunder. Sistem jaringan jalan primer merupakan sistem jaringan jalan dengan peranan pelayanan distribusi barang dan jasa untuk pengembangan semua wilayah di tingkat nasional, dengan menghubungkan semua simpul jasa distribusi yang berwujud pusatpusat kegiatan. Sistem jaringan jalan sekunder merupakan sistem jaringan jalan dengan peranan pelayanan distribusi barang dan jasa untuk masyarakat di dalam kawasan perkotaan. Jalan sesuai dengan peruntukannya terdiri atas jalan umum dan jalan khusus. Jalan umum tersebut dikelompokkan menurut sistem, fungsi, status, dan kelas.

Jalan umum menurut fungsinya dikelompokkan ke dalam jalan arteri, jalan kolektor, jalan lokal, dan jalan lingkungan. Jalan arteri merupakan jalan umum yang berfungsi melayani angkutan utama dengan ciri perjalanan jarak jauh, kecepatan rata-rata tinggi, dan jumlah jalan masuk dibatasi secara berdaya guna. Jalan arteri meliputi jalan arteri primer dan arteri sekunder. Jalan arteri primer merupakan jalan arteri dalam skala wilayah tingkat nasional, sedangkan jalan arteri sekunder merupakan jalan arteri dalam skala perkotaan. Jalan kolektor merupakan jalan umum yang berfungsi melayani angkutan pengumpul atau pembagi dengan ciri perjalanan jarak sedang, kecepatan rata-rata sedang, dan jumlah jalan masuk dibatasi. Jalan kolektor meliputi jalan kolektor primer dan jalan kolektor sekunder. Jalan kolektor primer merupakan jalan kolektor dalam skala wilayah, sedangkan jalan kolektor sekunder dalam skala perkotaan.

Jalan umum menurut statusnya dikelompokkan ke dalam jalan nasional, jalan propinsi, jalan kabupaten, jalan kota, dan jalan desa. Jalan nasional merupakan jalan arteri dan jalan kolektor dalam sistem jaringan jalan primer yang menghubungkan antar ibukota propinsi, dan jalan strategis nasional, serta jalan tol. Jalan strategis nasional adalah jalan yang melayani kepentingan nasional atas dasar kriteria strategis yaitu mempunyai peranan untuk membina kesatuan dan keutuhan nasional, melayani daerahdaerah rawan, bagian dari jalan lintas regional atau lintas internasional, melayani kepentingan perbatasan antar negara, serta dalam rangka pertahanan dan keamanan.

Jalan propinsi merupakan jalan kolektor dalam sistem jaringan jalan primer yang menghubungkan ibukota propinsi dengan ibukota kabupaten/kota, atau antar ibukota kabupaten/kota, dan jalan strategis propinsi. Jalan strategis propinsi adalah jalan yang diprioritaskan untuk melayani kepentingan propinsi berdasarkan pertimbangan untuk membangkitkan pertumbuhan ekonomi, kesejahteraan dan keamanan propinsi.

Dalam ilmu ekonomi seperti kita ketahui faktor-faktor produksi yang terdiri dari: tanah, modal, tenaga kerja, Skill. Salah satu faktor tersebut adalah tenaga kerja yang sesuaidengan keahlian dan ketrampilan yang dimiliki agar tenaga kerja yang dimiliki dalam sektor industri, modal utama yang dibutuhkan adalahsumber daya manusia.

Semakin bertambahnya jumlah industri kecil akan membawa dampaksangat luas terhadap penyerapan tenaga kerja, peningkatan SDM yangterbatas tentunya akan menghambat pengembangan itu sendiri,merupakan tugas dan tanggung jawab masyarakat secara bersamasama dengan pemerintah untuk menciptakan lapangan pekerjaan sertaberpartisipasi menunjang program pemerintah pada peningkatan taraf hidup yang lebih adil dan merata, lalu 
pemerintah memberikanbantuan dan penyuluhan.

Pada prinsipnya teori penawaran tenaga kerja dan teori permintaan tenaga kerja merupakan fungsi dari tingkat upah, di mana pendapat dari kaum klasik menyatakan, jika semakin tinggi tingkat upah yang diminta oleh kaum pekerja maka akan semakin sedikit jumlah penawaran tenaga kerja (lowongan kerja) yang dapat diberikan dan akan berlaku sebaliknya. Dalam memahami mekanisme pasar tenaga kerja harus dilihat bagaimana individu pekerja terdapat perbedaan, maka untuk menentukan kuva penawaran tenaga kerja pada suatu daerah adalah dengan menjumlahkan kurva-kurva penawaran dari setiap individu, oleh sebab itu kurva dari penawaran tenaga kerja berbentuk melengkung kebelakang (backward bending curve).

Menurut Kunarjo (2002:144-146) Pengeluaran Pemerintah (Government Expenditure) adalah pengeluaran oleh pemerintah untuk membeli barang dan jasa. Sebagian dari pengeluaran pemerintah adalah untuk membiayai administrasi pemerintahan atau pengeluaran rutin dan sebagian lainnya untuk membiayai kegiatan-kegiatanatau pembangunan atau pengeluaran pembangunan. Pengeluaran rutin pemerintah terdiri dari belanja pegawai, belanja barang, belanja pemeliharaan, belanja perjalanan dinas, angsuran pinjaman/hutang dan bunga, ganjaran subsidi dan sumbangan pada daerah, pensiun dan bantuan, pengeluaran yang tidak termasuk bagian lain, dan pengeluaran yang tak terduga.

Dalam Dumairy (1999:157) dikatakan bahwa pengeluaran pemerintah merupakan salah satu unsur permintaan agregat. Konsep perhitungan pendapatan nasional dengan pendekatan pengeluaran menyatakan bahwa : $\mathrm{Y}=$ $\mathrm{C}+\mathrm{I}+\mathrm{G}+\mathrm{X}-\mathrm{M}$ dimana variabel $\mathrm{Y}$ melambangkan pendapatan nasional, sekaligus mencerminkan penawaran agregat. Sedangkan variabel di sebelah kanan disebut permintaan agregat. Variable $\mathrm{G}$ melambangkan pengeluaran pemerintah atau (Government Expenditures). Dengan membandingkan nilai $G$ terhadap $Y$, serta mengamatinya dari waktu ke waktu, dapat diketahui seberapa besar kontribusi pengeluaran pemerintah dalam pembentukan permintaan agregat atau pendapatan nasional. Dapat pula dianalisis seberapa penting peranan pemerintah dalam perekonomian nasional.

WW Rostow dan RA Musgrave menghubungkan pengeluaran pemerintah dengan tahap-tahap pembangunan ekonomi. Pada tahap awal perkembangan ekonomi, rasio investasi pemerintah terhadap investasi total (rasio pengeluaran pemerintah terhadap pendapatan nasional) relatif besar. Hal ini disebabkan pada tahap awal pemerintah harus menyediakan berbagai sarana dan prasarana. Pada tahap menengah pembangunan ekonomi, investasi pemerintah tetap diperlukan guna memacu pertumbuhan agar dapat lepas landas. Bersamaan dengan itu porsi investasi pihak swasta juga meningkat, tetapi besarnya peranan pemerintah adalah karena pada tahap ini banyak terjadi kegagalan pasar yang ditimbulkan oleh perkembangan ekonomi itu sendiri.

Studi empirisFatas dan Mihov (1998) menyatakan bahwa pengeluaran pemerintah Amerika Serikat berpengaruh positif dan signifikan terhadap ketersediaan kesempatan kerja. Hasil berbeda dari penelitian Sun'an dan Astuti (2008) dalam menganalisis pengaruh investasi, pengeluaran pemerintah, dan pertumbuhan ekonomi 
terhadap kesempatan kerja di Nusa Tenggara Barat yaitu kebijakan fiskal melalui pengeluaran pemerintah (APBD) tidak berpengaruh terhadap penciptaan kesempatan kerja di Provinsi NTB.

Berdasarkan latar belakang penelitian dan kerangka pemikiran, dapat dirumuskan hipotesis bahwa alokasi APBD berpengaruh nyata terhadap penyerapan tenaga kerja di Kabupaten Jember.

\section{METODE PENELITIAN}

Jenis penelitian ini termasuk dalam kategori penelitian dengan pendekatan analisis diskriptif komparatif-kuantitatif yaitu metode penelitian yang dilakukan untuk memecahkan masalah yang terjadi saat ini melalui analisa tentang perhubungan-perhubungan sebab akibat yakni yang memiliki faktor-faktor tertentu yang berhubungan dengan situasi atau fenomena yang diselidiki dan membandingkan satu faktor dengan faktor lainya (Surakhmad, 1990: 139).Unit analisis yang digunakan dalam penelitian ini adalah dinamika pengeluaran pemerintah daerah Kabupaten Jember dan penyerapan tenaga kerja sejak tahun 2004 dan 2013. Untuk mengetahuiperkembangan penyerapan tenaga kerja di Kabupaten Jember tahun 2004 dan 2013 digunakananalisa trend denganmetodekuadratterkecil. Selain itu, alat analisis yang digunakan Korelasi bivariate/product moment pearson.Korelasi ini mengukur keeratan di antara hasil-hasil pengamatan dari populasi yang mempunyai dua varian (bivariate).

\section{HASIL PENELITIAN DAN PEMBAHASAN}

\section{Hasil Penelitian}

Perkembangan ekonomi suatu daerah baik propinsi maupun kabupaten atau kota dapat dilihat dari tingkat penyerapan tenaga kerjanya. Penyerapan tenaga kerja merupakan aspek penting dalam keberhasilan pembangunan. Krisis moneter dan ekonomi secara signifikan telah mempengaruhi dinamika kehidupan sektor andalan tersebut apabila sektor tersebut mengalami kontraksi, maka secara otomatis struktur ekonomi juga akan mengalami pergerakan karena sumbangannya yang cukup besar sehingga akan berdampak pada penyerapan tenaga kerja.

Untuk melihat Trend perkembangan penyerapan tenaga kerja selama kurun waktu tahun 2004 - 2013 maka dapat diuraikan sebagai berikut;

$Y=1108321+76526,42 X$

1. Nilai konstanta sebesar 1108321 adalah koefisien ini menunjukkan bahwa pada saat trend perkembangan penyerapan tenaga kerja konstan dan dalam perekonomian yang stabil, maka penyerapan tenaga kerja Kabupaten Jember akan naik sebesar 1108321 orang.

2. Nilai koefisien trend perkembangan penyerapan tenaga kerja sebesar 76526,42 adalah koefisien ini menunjukkan adanya pengaruh positif, apabila terjadi kenaikan trend sebesar satu persen maka akan meningkatkan penyerapan tenaga kerja Kabupaten Jember sebesar 76526,42 orang dengan asumsi faktor- faktor lain dianggap tetap. 


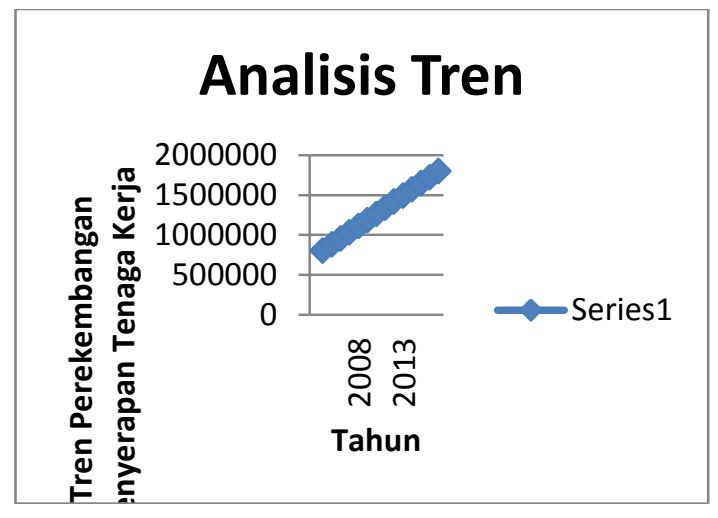

\section{Gambar 1 Analisis Trend Sumber: data diolah}

Berdasarkan gambar 1 diatas, penyerapan tenaga kerja di kabupaten Jember diperkirakan akan semakin meningkat. Hal ini terlihat pada analisis trend yang bertanda positif. Berdasarkan anlisis trend, penyerapan tenaga kerja di Kabupaten Jember pada tahun 2014 mencapai 1.567.480 orang dan mengalami peningkatan pada tahun 2015 mencapai 1.644.006 orang. Peningkatan ini akan berlanjut hingga tahun perkiraan 2018 dengan capaian penyerapan tenaga kerja di Kabupaten Jember 1. 873.586 orang.

Penyerapan tenaga kerja tidak pernah lepas dari pengangguran yang ditimbulkan oleh pihak pengusaha. Tingkat pengangguran merupakan salah satu indikator kondisi perekonomian di suatu negara. Dalam kondisi perekonomian yang memburuk, banyak perusahaan yang tidak berkembang, mengalami penciutan usaha, atau bahkan mengalami kebangkrutan. Oleh karena itu kesempatan yang tersedia di pasar semakin kecil. Akibat bagi pencari kerja adalah mereka mengalami persaingan yang lebih ketat dalam memperebutkan kesempatan kerja yang relatif kecil. Mereka yang tidak dapat memenangkan persaingan ini akan menjadi pengangguran

Tabel 1 Correlations

\begin{tabular}{|r|r|r|}
\hline & APBD & $\begin{array}{c}\text { Bekerj } \\
\mathrm{a}\end{array}$ \\
\hline $\begin{array}{c}\text { APBD Pearson } \\
\text { Correlation } \\
\text { Sig. (2-tailed) }\end{array}$ & 1 & .604 \\
$\mathrm{~N}$ & 10 & .065 \\
\hline $\begin{array}{l}\text { Bekerj Pearson } \\
\text { Correlation } \\
\text { Sig. (2-tailed) } \\
\mathrm{N}\end{array}$ & .065 & 10 \\
\hline
\end{tabular}

Sumber; data diolah

Berdasarkan table diatas, Koerisien korelasi antara pengeluaran pemerintah dan penyerapan tenaga kerja adalah 0,604. Angka tersebut menunjukkan hubungan yang kuat antara pengeluaran pemerintah dan penyerapan tenaga kerja. Disamping itu, nilai koefisien korelasi bertanda positf. Hal ini memberi tanda bahwa hubungan antara pengeluaran pemerintah dan penyerapan tenaga kerja besifat searah sehingga dapat diartikan peningkatan pengeluaran pemerintah Kabupaten Jember akan berdampak pada peningkatan penyerapan tenaga kerja di Kabupaten Jember.

Nilai probabilitas yang ditunjukkan dalam signifikan 2-tailed sebesar 0,65. Hal ini menunjukkan bahwa korelasi antara pengeluaran 
pemerintah dan penyerapan tenaga kerja tidak signifikan. Artinya pengeluaran pemerintah bukanlah satu-satunya factor terbesar dalam penyerapan tenaga kerja di Kabupaten Jember.

\section{PEMBAHASAN}

Penyerapan tenaga kerja masih relative lambat akibat dari lambatnya penciptaan lapangan kerja formal perlu dicari jalan keluarnya. Tingginya tingkat pengangguran terbuka berpotensi menimbulkan berbagai kerawanan sosial. Di samping pengangguran terbuka, besarnya jumlah setengah penganggur terpaksa membutuhkan perhatian bersama. Untuk itu pemerintah menempatkan penciptaan lapangan kerja sebagai salah satu prioritas yang sangat mendesak. Menurunkan tingkat pengangguran terbuka dan setengah penganggur dengan menciptakan lapangan kerja produktif melalui investasi mendapat perhatian yang sungguh-sungguh dari pemerintah. Salah satu aspek untuk memperbaiki iklim investasi adalah dengan memperbaiki iklim ketenagakerjaan.

Selain itu, penciptaan lapangan kerja formal juga masih belum dapat menutup berkurangnya lapangan kerja formal selama periode sebelumnya. Lapangan kerja formal hanya menyerap tenaga kerja sekitar 30 persen dari angkatan kerja. Pengurangan lapangan kerja formal terjadi justru terjadi pada industri-industri yang padat pekerja yang sebagian berorientasi ekspor. Pengurangan lapangan kerja formal ini memberikan tekanan kepada kesejahteraan pekerja informal.

Angkatan kerja yang berpendidikan SD dan SD ke bawah jumlahnya juga masih cukup besar, yaitu 38,52 persen dari jumlah angkatan kerja pada tahun 2013 di Kabupaten Jember. Masih besarnya jumlah dan persentase angkatan kerja yang berpendidikan rendah mencerminkan masih rendahnya kualitas angkatan kerja yang tersedia. Kondisi ini seringkali menimbulkan ketidaksesuaian kebutuhan di pasar kerja. Berkaitan dengan permasalahan ini, masih perlu dilakukan penyempurnaan pengembangan program-program pelatihan dan penyelenggaraan pelatihan kerja. Keterbatasan dalam penyediaan sarana dan prasarana pelatihan, khususnya pada balai latihan kerja milik pemerintah, menyebabkan lembaga pelatihan belum sepenuhnya dapat memenuhi kebutuhan pasar kerja yang terus berkembang.

Belum adanya standardisasi dan sertifikasi kompetensi tenaga kerja secara nasional menyebabkan banyak lembaga pelatihan, termasuk lembaga pelatihan milik Pemerintah, yang memberikan sertifikasi pekerja menggunakan standar yang berbedabeda. Untuk itu, perlu adanya pengakuan dan komitmen bersama berkaitan dengan standardisasi dan sertifikasi tenaga kerja.

Dengan jumlah pengangguran yang demikian besar, sebagian besar bekerja pada lapangan kerja informal, sebagian besar memiliki tingkat pendidikan formal dan keterampilan yang rendah serta umumnya masih berusia muda, setidaknya terdapat dua tantangan besar yang dihadapi, yaitu menciptakan lapangan pekerjaan formal atau modern yang seluas-luasnya. Oleh karena itu, juga menjadi tantangan bagi Pemerintah untuk dapat menggairahkan iklim berusaha sehingga memiliki daya tarik bagi investor agar berminat menanamkan modalnya di Indonesia. Semua ini bertujuan agar dapat membuka lapangan kerja baru. Dalam hal ini diperlukan kebijakan yang dapat 
memberikan iklim usaha yang kondusif. Iklim yang kondusif di sini berarti adanya stabilitas ekonomi, termasuk politik dan keamanan, serta biaya produksi yang rendah dan yang lebih penting lagi adanya kepastian hukum.

Selain itu,perlu memberikan dukungan yang diperlukan agar pekerja dapat berpindah dari pekerjaan dengan produktivitas rendah ke pekerjaan dengan produktivitas tinggi. Dengan kata lain, pekerja informal dapat secara bertahap pindah ke lapangan kerja formal.

Dalam upaya mendukung tercapainya pertumbuhan ekonomi yang tinggi, pemerintah daerah sebagai otoritas pembangunan dituntut untuk menerapkan kebijakan yang dapat menciptakan iklim yang kondusif bagi kegiatan-kegiatan produktif para pelaku ekonomi. Salah satu kebijakan yang diperlukan untuk mencapai pertumbuhan tersebut adalah dengan mendorong terciptanya iklim investasi yang baik. Peran pemerintah daerah dapat dijalankan melalui salah satu instrumen kebijakan, yaitu pengeluaran pemerintah (baik belanja rutin maupun pembangunan dan atau pemeliharaan dan belanja modal), dimana pengeluaran pemerintah mencerminkan biaya yang harus dikeluarkan oleh pemerintah untuk melaksanakan kebijakan tersebut. Pengeluaran pembangunan (dan atau belanja modal dan pemeliharaan) merupakan pengeluaran pemerintah untuk pelaksanaan proyek-proyek terdiri dari sektor sektor pembangunan dengan tujuan untuk melakukan investasi.

Meskipun demikian, pengeluaran pemerintah tidak pernah mengalami penurunan justru semakin naik. Peningkatan pengeluaran pemerintah merupakan konsekuensi dari ditentukannya program kerja yang membutuhkan anggaran yang besar. Pengeluaran pemerintah merupakan seperangkat produk yang dihasilkan yang memuat pilihan atau keputusan yang dibuat oleh pemerintah untuk menyediakan barang-barang publik dan pelayanan kepada masyarakat. Menurut Mangkoesubroto

(1998;169)

Pengeluaran pemerintah mencerminkan kebijakan pemerintah. Apabila pemerintah telah menetapkan suatu kebijakan untuk membeli barang dan jasa, pengeluaran pemerintah mencerminkan biaya yang harus dikeluarkan oleh pemerintah untuk melaksanakan kebijakan tersebut.

Pengeluaran pemerintah dalam arti riil dapat dipakai sebagai indikator besarnya kegiatan pemerintah yang dibiayai oleh pengeluaran pemerintah itu. Semakin besar dan banyak kegiatan pemerintah, semakin besar pula pengeluaran pemerintah yang bersangkutan. Proporsi pengeluaran pemerintah terhadap penghasilan nasional (GNP) adalah suatu ukuran terhadap kegiatan pemerintah dalam suatu perekonomian. Pada tahap awal perkembangan ekonomi, persentase investasi pemerintah terhadap total investasi besar sebab pada tahap ini pemerintah harus menyediakan prasarana. Pada tahap menengah investasi pemerintah tetap diperlukan untuk menghindari terjadinya kegagalan pasar yang disebabkan oleh investasi swasta yang sudah semakin besar pula. Pada tingkat ekonomi yang lebih lanjut, aktivitas pemerintah beralih pada bentuk pengeluaran untuk aktivitas-aktivitas sosial. Suatu tinjauan teoritis menyatakan bahwa dalam suatu perekonomian, apabila pendapatan perkapita meningkat, secara relatif 
pengeluaran pemerintah pun akan meningkat.

\section{Dikabupaten}

Jember,

Pengeluaran pemerintah juga berkorelasi kuat terhadap penyerapan tenaga kerja dengan koefisien korelasi mencapai 0,604. Dengan asumsi variabel lain adalah tetap, kenaikan satu persen pengeluaran pemerintah dapat menaikkan penyerapan tenaga kerja di Kabupaten Jember. Hal ini sesuai dengan teori bahwa kenaikan pengeluaran pemerintah dapat menaikkan penyerapan tenaga kerja.

Pengeluaran pemerintah dapat memperbesar output yang dihasilkan oleh suatu sektor ekonomi. Selain itu, juga dapat menaikkan pendapatan masyarakat karena pengeluaran pemerintah akan menjadi penerimaan masyarakat sehingga mendorong permintaan agregat. Karena adanya kenaikan permintaan agregat sehingga mendorong produsen untuk meningkatkan output produksinya. Untuk itu, produsen memerlukan tambahan input produksi, salah satunya adalah tenaga kerja, sehingga akan tercipta kesempatan kerja baru. Dengan demikian, kenaikan pengeluaran pemerintah akan menambah kesempatan kerja baru bagi masyarakat. Proyekproyek yang dibiayai oleh pemerintah seperti membangun jalan, sekolah, atau fasilitas lain umumnya bersifat padat karya sehingga dapat menaikkan penyerapan tenaga kerja.

Hasil penelitian ini juga sesuai dengan hipotesis Minsky (1974) dalam Prasetyantoko (2008) bahwa pengangguran tidak bisa diatasi tanpa campur tangan pemerintah. Dalam hal ini, pasar tidak akan dengan sendirinya menyelesaikan persoalan pengangguran serta derivasi masalah yang ditimbulkannya sehingga pemerintah harus lebih meningkatkan pengeluaran pembangunan yang nantinya akan merangsang penyerapan tenaga kerja.

Selain itu, Studi empiris Fatas dan Mihov (1998) menyatakan bahwa pengeluaran pemerintah Amerika Serikat berpengaruh positif dan signifikan terhadap ketersediaan kesempatan kerja. Hasil berbeda dari penelitian Sun'an dan Astuti (2008) dalam menganalisis pengaruh investasi, pengeluaran pemerintah, dan pertumbuhan ekonomi terhadap kesempatan kerja di Nusa Tenggara Barat yaitu kebijakan fiskal melalui pengeluaran pemerintah (APBD) tidak berpengaruh terhadap penciptaan kesempatan kerja di Provinsi NTB.

\section{KESIMPULAN DAN SARAN}

Sesuai dengan tujuan analisis, studi ini ingin mengetahui pengaruh alokasi APBD yaitu pengeluaran pemerintah terhadap penyerapan tenaga kerja di Kabupaten Jember. Berdasarkan analisis pada Bab 6, maka dapat diambil kesimpulan antara lain sebagai berikut :

1. Penyerapan tenaga kerja di Kabupaten Jember akan semakin meningkat, hal ini berdasarkan analisis tren perkembangan penyerapan tenaga kerja

2. Korelasi antara pengeluaran pemerintah Kabupaten Jember dengan penyerapan tenaga kerja di Kabupaten Jember sangat kuat dan searah.

Berangkat dari hasil kesimpulan diatas, maka timbul pemikiran kedepan yang tertuang dalam saran sebagai berikut : 
1. Meningkatkan pengeluaran pemerintah Kabupaten Jember pada guna menyerap tenaga kerja

2. Pengeluaran pembangunan sebaiknya diarahkan pada kegiatan yang bersifat produktif seperti peningkatan kualitas sumber daya manusianya. Peningkatan sumber daya manusia dapat dilakukan melalui program-program pendidikan dan pelatihan.

3. Meningkatkan investasi swasta dengan menciptakan iklim investasi yang kondusif di Kabupaten Jember serta menjaga persaingan usaha antar badan usaha guna terciptanya laju pertumbuhan ekonomi yang tinggi dan dinamis.

4. Meningkatkan kepastian berusaha dan kepastian hukum bagi dunia usaha, termasuk usaha kecil dan menengah, serta meningkatkan daya saing industri

\section{DAFTAR PUSTAKA}

Arsyad, Lincolin, 1999, Ekonomi Pembangunan. Yogyakarta: Badan Penerbit Fakultas Ekonomi (BPFE)

BPS. 2013. Jember Dalam Angka. Jember: BPS Kabupaten Jember

Devas, 1988 Kesadaran Budaya Tentang Tata Ruang Di Daerah Kalimantan Selantan. Jakarta: Departemen Pendidikan dan Kebudayaan.

Dumairy. 1999. Perekonomian Indonesia. Jakarta : Erlangga.
Fatas A, and Mihov I. 1998. The Effects of Fiscal Policy on Consption and Employment: Theory and Evidence. Seminar participants at Tilburg University, ECARES, University of Toulouse and The European Summer Symposium on International Macroeconomics Gujarati. 2003. Ekonometrika Dasar.Terjemahan. Jakarta: Erlangga.

Harijono, Gatot Setio dan Utama,I Made Suyana (2011), Analisis Pengaruh Pengeluaran Pemerintah Dan Investasi Terhadap Kesempatan Kerja Melalui Pertumbuhan Ekonomi. Bali. FE Udayana Bali

Irawan, dan Suparmoko. 1987. Ekonomi Pembangunan. Yogya : Liberty.

Kunarjo, 2002.Perencanaan dan Pengendalian Program Pembangunan.Jakarta : UI Press.

Kuncoro, Mudrajad 2003. Metode Riset Untuk Bisnis dan Ekonomi. Jakarta: Erlangga

Mursinto, Djoko, 2005, Derajat Desentralisasi Fiskal dan Tingkat Kemandirian Keuangan Pada Era Otonomi Daerah Pemerintahan Kabupaten dan Kota di Provinsi Jawa Timur, Disertasi, tidak dipublikasikan. Surabaya : Pascasarjana Unair.

Musgrave Richard A, and Musgrave, Peggy B, 1980.Public Finance in Theory and Practice.Singapura : International Student Edition, Third Edition, Mc Graw Hill International Book Company..

Prassman, 2000. : Statistika. Analisis Nubungan Kausal Berdasarkcrn 
Data Kategotik. Jakarta: PT. Raja Grafindo. Nusantara

Simanjuntak, Payaman, 1999, Pengantar Ekonomi Sumberdaya Manusia, Edisi 2001, Lembaga Penerbit Fakultas Ekonomi UI. Jakarta.

Sukirno, Sadono. 1981. Pengantar Teori Ekonomi Makroekonomi. Jakarta : LPFE Universitas Indonesia.

Sun'an Muammil \& Astuti Endang. 2008. Analisis Investasi, Pengeluaran Pemerintah dan Pertumbuhan Ekonomi Terhadap Kesempatan Kerja Di Provinsi Nusa Tenggara Barat. Vol. 1 No. 1 : Iqtishodunia

Supranto. $1995 . \quad$ Ekonometrik. Yogyakarta: BPFE. 